\begin{tabular}{|c|c|}
\hline \multirow{3}{*}{ 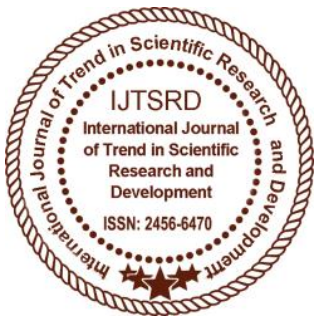 } & $\begin{array}{l}\text { International Journal of Trend in Scientific } \\
\text { Research and Development (IJTSRD) }\end{array}$ \\
\hline & International Open Access Journal \\
\hline & ISSN No: 2456 - 6470 | www.ijtsrd.com | Volume - 1 | Issue - 5 \\
\hline
\end{tabular}

\title{
Microbial Decolorization of Leather Dye Effluent
}

\author{
Dr. Jitender Kumar \\ Head, Department of Biotechnology, \\ Hans Raj Mahila Mahavidyalaya, Jalandhar
}

\author{
Navleen Kaur Chopra \\ Research Scholar (Ph.D.), I.K. Gujral Punjab \\ Technical University, Kapurthala
}

\begin{abstract}
As we know $71 \%$ of Earth's Surface is covered with water. Water is one of the most essential element for the persistence of life on this planet. Pure and contamination free water is the dire necessity of every living being present on Earth but today water pollution has posed great threat to the existence of life. The discharge of effluents from various industries into the water bodies are mainly responsible for water pollution specially effluents from leather industry are the most contaminating as along with the harmful chemicals they contain organic matter as well. The dyes disposed by the leather industry are the most harmful for the environment. The conventional physicochemical methods used for the treatment of leather dyes in the contaminated water i.e. coagulation, precipitation, oxidation etc have disadvantages and limitations. This study presents microbial decolorization of leather dye effluents from Shigella sp. isolated from effluent samples collected from leather industry. Different parameters such as temperature and $\mathrm{pH}$ were optimized for decolorization of Methylene Blue, Crystal Violet, EosinYellow, Safranine dyes by using bacterial isolates. Optimum temperature for decolorization was observed to be $30^{\circ} \mathrm{c}$, the optimum $\mathrm{pH}$ range for decolorization was found to be from $\mathrm{pH} 6-\mathrm{pH} 8$. All the samples were incubated at $30^{\circ} \mathrm{C} 150 \mathrm{rpm}$. The decolorization was measured as decrease in absorbance maxima at 663 $\mathrm{nm}, 590 \mathrm{~nm}, 518 \mathrm{~nm}, 530 \mathrm{~nm}$ for mehtylene blue, crystal violet, eosin yellow, safranine respectively.
\end{abstract}

Keywords: shigella sp. Crystal Violet, Methylene Blue.Eosin Yellow, Safranine

\section{INTRODUCTION}

Potable water is one of the primary necessities for the existence of life on this earth. Water is essential for daily human activities may it be for domestic purposes, industrial or agricultural purposes. With the increase in urbanization and industrialization the environment has been remarkably affected by man. With the increase in population we have witnessed a rapid increase in pollution mainly water pollution. The discharge of effluents from industries into the water bodies has emerged out to be the main culprit of water pollution. Indian tannery industry is one of the leading tannery industries in the world but with that it also one of highly polluting industry. Tannery effluents lead to both water as well as air pollution. On the basis of volume of tannery effluents and its composition it has been regarded as most polluting among all [2], [4], [13], [15]. The studies have reported that waste water discharged from tannery industry have greater values of BOD, COD, color and $\mathrm{pH}$ [14], [17].

The colored components of tannery effluent along with organic load causes ecological imbalance in the receiving water body [9]. Tannery waste water discharges large amount of dye during washing operations [8]. These dyes are mainly xenobiotic and also carcinogenic in some cases [3]. Studies have also reported allergic effect of these dyes [11], [12]. If not 
International Journal of Trend in Scientific Research and Development (IJTSRD) ISSN: 2456-6470

treated properly these dyes persist in the environment Use of synthetic dye is more prevalent than natural dyes as they are cost effective their production is easy, large variety of shades can be produced moreover due to comparative fastness of colour than natural dyes. More than 100,000 dyes are commercially available and about one million ton of these dyes are produced annually worldwide [1]. During industrial process, approximately $10-15 \%$ of these dyes are released into the environment [6] due to their chemical nature these dyes pose great threat to environment.

Addition of colour to water is the main indication of the water pollution. Highly coloured synthetic dyes block the entry of sunlight in the receiving water body, hence are fatal for flora and fauna living in it. Moreover dyes and their breakdown product are cytotoxic and carcinogenic [7]. A number of physiochemical methods such as coagulation, filtration, precipitation, oxidation etc. have been used to treat effluent containing synthetic dyes, but these methods have many disadvantages and limitations. It is therefore important to develop efficient and cost effective methods for decolorization and degradation of dyes in tannery effluents.

In situ degradation of dyes by microorganisms is a novel method for treatment of effluent. In this method, the microorganisms isolated from the site of pollution can be used for the treatment of effluent [9]. The present study aims to isolate dye decolorzing microorganisms from the tannery effluents. As the microbial isolates will be isolated from the tannery wastewater, they can easily adopt the prevailing environment. Such microorganisms can be used to develop effective biological treatment system for waste water contaminated with leather dyes. Further present research aims to study the decolorization capacity of such microorganisms by screening them from effluent, isolation and optimization of decolorization conditions (temperature, $\mathrm{pH}$ etc.), hence to produce a system to treat leather dyes in an ecofriendly manner with the help of microbes.

\section{MATERIALS AND METHODS:}

\section{$>$ Chemicals and Media}

Dye effluents were collected from a Leather Complex Jalandhar Punjab. All microbiological media and medium ingredients were purchased from HiMedia Laboratories (Mumbai, MH, India). for a long duration of time.

\section{Isolation dye degrading Bacteria}

The Leather Dye containing effluent sample was collected from a Leather industry located at Jalandhar, Punjab. One $\mathrm{ml}$ of effluent was transferred into $9 \mathrm{ml}$ of distilled water in sterile test tubes. Serial dilution was done up to 10 by thorough mixing. $0.1 \mathrm{ml}$ of sample from each dilution was spread on Nutrient Agar plates containing with the help of sterile L-rod. The petridishes were incubated at $30^{\circ} \mathrm{C}$ for 24 hours from these bacterial colonies were isolated by Streak Plate Method.

\section{Preservation and maintenance}

Pure bacterial isolates were obtained on the Nutrient agar plates were stored in refrigerator and served as stock cultures. Subcultures were routinely made every 7 to 10 days.

\section{Screening of decolorizing Bacteria}

All the isolates were selected for screening of decolorizing activity of dye. Inoculums each isolate were added to $100 \mathrm{ml}$ of Nutrient Broth and were incubated at $30{ }^{0} \mathrm{C}$ for 48 hours. $1 \%$ of dye solution was serially diluted from $10^{-1}$ to $10^{-5}$. These solutions were inoculated with $1 \%$ of nutrient broth and incubated at $30{ }^{0} \mathrm{C}$ for 6 days. After 6 days, effective decolorization was seen visually. Those isolates showing decolorization of textile dye effluent were selected for further studies with decolorization of synthetic dyes methylene blue, crystal violet, eosin yellow, safranine. The bacterial strain found to be potential in dye decolorization was selected and best decolorization results were observed in $10^{-4}$ dilution.

\section{Biochemical characterization}

Furthermore the microbial isolate selected on the basis of optimum decolourization activity was characterized biochemically as well as physiologically up to species level.

\section{$>$ Decolorization assay}

Decolorization activity in terms of percent decolorization was determined by following method described by (Ponraj et.al). $10 \mathrm{ml}$ of sample was centrifuged at $1000 \mathrm{rpm}$ for 10 minutes. Spectrophotometer was used for absorbance measurement. The decrease in absorbance was monitored at $663 \mathrm{~nm}, 590 \mathrm{~nm}, 518 \mathrm{~nm}, 530 \mathrm{~nm}$ for Methylene Blue, Crystal Violet, Eosin Yellow and Safranine respectively. Decolorization activity was 
International Journal of Trend in Scientific Research and Development (IJTSRD) ISSN: 2456-6470

calculated according to the following formula: $D=[A$ $-F) / A$ ] $\times 100$

Where: D, decolourization; A initial absorbance; F final absorbance (ponraj et .al)[10].

\section{Dye Decolorization Optimization}

Decolorization of methylene blue, crystal violet, eosin yellow, safranine by selected bacterial isolate was optimized with respect to the effect temperature $\left(4^{0} \mathrm{C}\right.$, $\left.27^{0} \mathrm{C}, 37^{0 \mathrm{C}}, 60^{\circ} \mathrm{C}\right)$ and $\mathrm{pH}(2,4,6,8,10)$. Dye solution without culture served as control. All the test tubes were incubated at $30{ }^{\circ} \mathrm{C}$ under shaking conditions 100 rpm for 6 days.

\section{RESULTS AND DISCUSSION}

The complication faced during treatment of water pollution is the degradation of synthetic dyes disposed in the water bodies through industrial effluents. Tannery effluents being most polluting need to be paid most attention. Indian tanning industry is one of the leading tanning industries in the world. The tanning of leather involves use of many toxic chemicals to process and dye the leather. These chemicals cause life threatening problems like cancer, damage to lungs and kidneys etc. to the living being coming in contact with them. So there is an urgent requirement for the treatment of the water polluted by the effluents from various industries specially the dye containing effluent from the leather industry. The method devised has to be eco-friendly and cost effective so as to make it viable on large scale. In the present study microbial decolourization of leather dye effluent was carried out using the bacterial isolate obtained from the leather dye effluent. Leather dye effluent samples were collected from the disposal site of effluent for screening efficient microorganisms, (bacteria).

\section{Screening of dye decolorization Bacteria}

The obtained bacterial isolates showed decolorization of dyes after 6 days of incubation at $30^{\circ} \mathrm{C}$ under shaking $(100 \mathrm{rpm})$. In the present investigation the rate of color removed increased with incubation periods.

\section{Bacterial isolated by streak plate method}

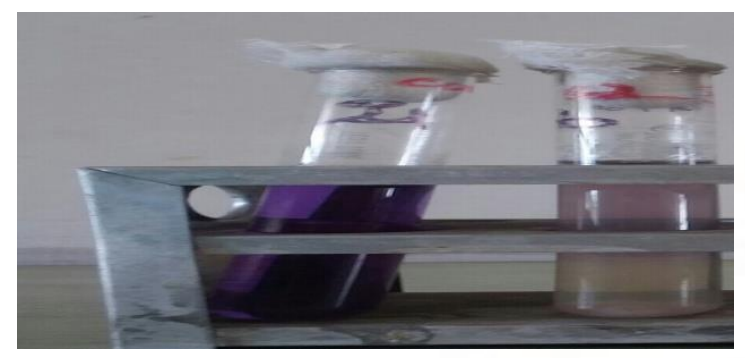

Decolorization of Crystal Violet dye after 6 days incubation

\section{Biochemical Characterization}

Biochemical characterization of the bacterial isolate revealed the following results:-

\begin{tabular}{|l|l|}
\hline TEST & RESULT \\
\hline H2S (TSI) & - \\
Urease & - \\
Indole & Variable \\
Methyl red $\left(37^{0} \mathrm{C}\right)$ & + \\
Voges-Proskauer( $\left.37^{0} \mathrm{C}\right)$ & - \\
Simmons' citrate & - \\
Christensen's citrate & - \\
Sodium acetate & - \\
Mucate & - \\
KCN & - \\
Motility & - \\
Sodium malonate & - \\
Lysine decarboxylase & - \\
Arginine dihydrolase & - \\
Ornithine decarboxylase & - \\
Phenylalanine deaminase & - \\
Galactosidase (ONPG) & - \\
Catalase & + \\
Oxidase & - \\
Glucose (acid) & + \\
Glucose (gas) & - \\
Lactose & - \\
Sucrose & - \\
Mannitol & - \\
Salicin & - \\
Adonitol & - \\
Dulcitol & - \\
Inositol & - \\
Arabinose & - \\
Sorbitol & - \\
Raffinose & - \\
Rhamnose & - \\
Maltose & - \\
Xylose & \\
Trehalose & - \\
\hline
\end{tabular}




\begin{tabular}{|l|l|}
\hline Cellobiose & - \\
Mannose & + \\
Glycerol & + \\
Esculin & - \\
\hline
\end{tabular}

The potential strain was identified as Shigella sp.

\section{$>$ Optimization of dye Decolorization}

For the maximization of decolourization of the dyes Methylene Blue, Crystal Violet, Eosin Yellow, Safranine by the selected bacterial isolates, experiments were conducted for optimization of temperature and $\mathrm{Ph}$.

\section{Effect of Temperatures}

Different temperatures used were as refrigerator temperature $\left(4^{\circ} \mathrm{C}\right)$, room temperature $\left(27^{\circ} \mathrm{C}\right)$, incubator temperature $\left(37^{\circ} \mathrm{C}\right)$ and extreme temperatures $\left(60{ }^{\circ} \mathrm{C}\right)$. The maximum decolorization was observed $27 \mathrm{C}$ followed by $37 \mathrm{C}$ and $4 \mathrm{C}$, least decolorizaton was observed at $60^{\circ} \mathrm{C}$ as cells does not remain viable at high temperatures(Figure- 1). Similar results were obtained by Ponraj et.al [10] who used by different bacterial strains for studying decolorization.

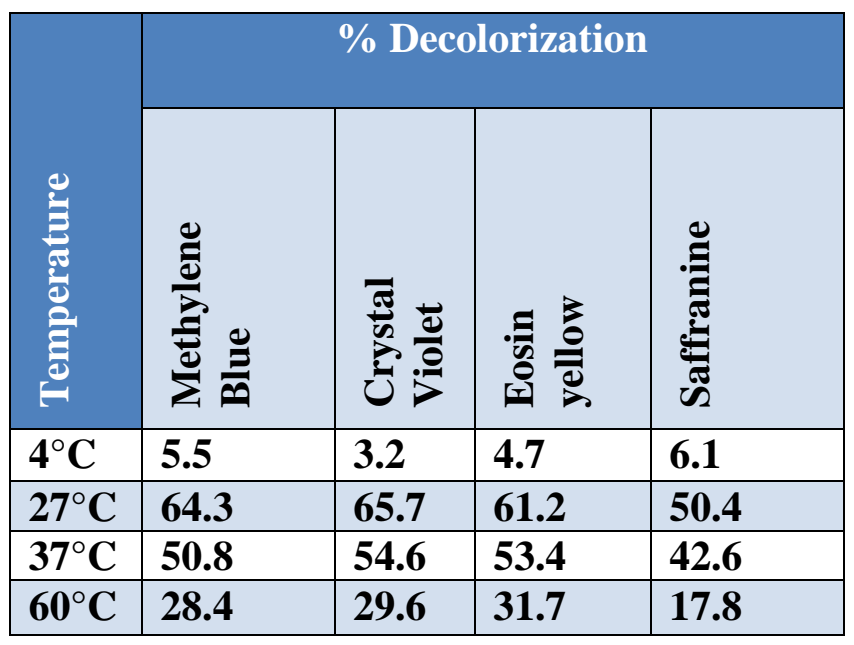

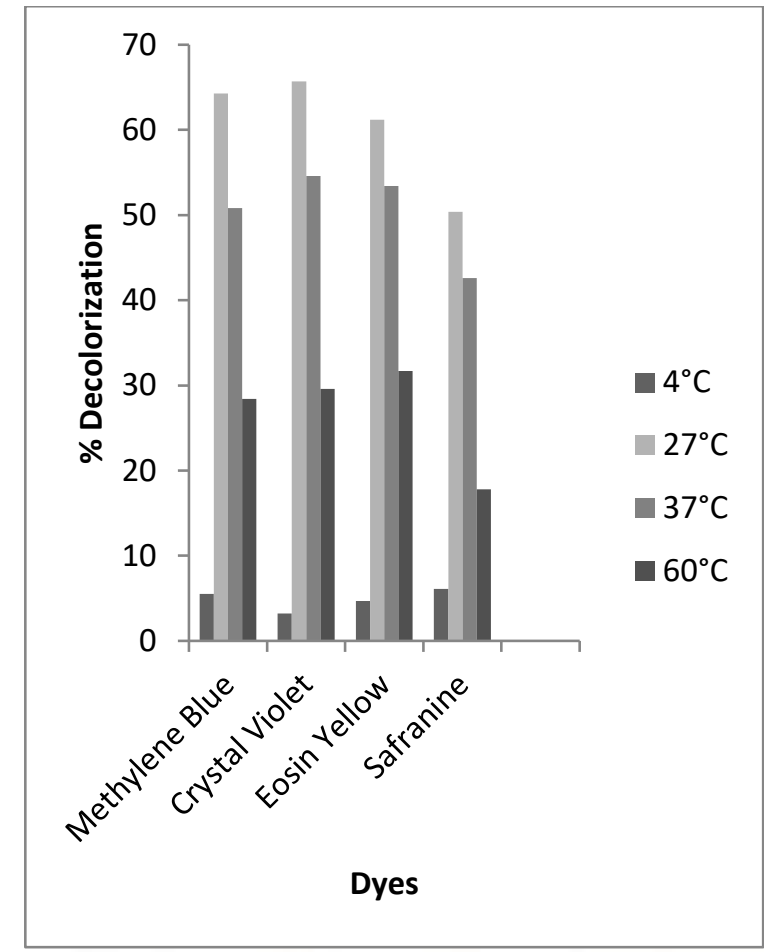

Figure -1 Effect of temperature on decolorzation of dyes by Shigella $S p$.

\section{Effect of pH}

The five bacterial isolates were grown in medium with different $\mathrm{pH}(2,4,6,8,10)$. The $\mathrm{pH}$ of the medium was adjusted with $\mathrm{HCl}$ and $\mathrm{NaOH}$. The maximum percentage decolorization was observed between $\mathrm{pH} 6$ to 8. (Figure-2) Similar results were seen in studies carried by Wong et.al and $\mathrm{Hu}$ et.al [16], [5].

\begin{tabular}{|c|c|c|c|c|}
\hline \multirow[t]{2}{*}{$\mathrm{pH}$} & \multicolumn{4}{|c|}{ \% Decolorization } \\
\hline & $\sum_{0}^{\frac{\pi}{2}}$ & 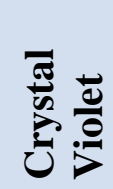 & 战 & 节 \\
\hline 2 & 2.6 & 3.5 & 4.9 & 6.9 \\
\hline 4 & 24.8 & 25.5 & 21.6 & 23.6 \\
\hline 6 & 50.8 & 54.6 & 53.4 & 42.5 \\
\hline 8 & 58.4 & 59.4 & 55.7 & 58.7 \\
\hline 10 & 16.7 & 17.6 & 18.7 & 19 \\
\hline
\end{tabular}




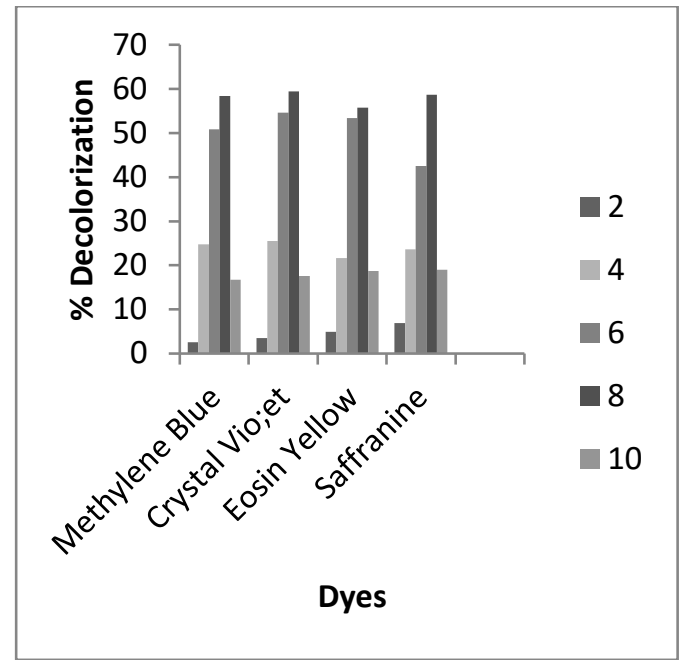

\section{Figure -2 Effect of pH on decolorzation dyes by Shigella Sp.}

\section{CONCLUSION}

The present study reveals that all the four dyes methylene blue, crystal violet, eosin yellow, safranine are degradable under aerobic conditions with Shigela isolated from textile dye effluent.The bacteria exhibhited maximum decolorization ability between pH6-pH8 Whereas temperature did not showed considerable effect on on decolorization $27^{\circ} \mathrm{C}-37^{\circ} \mathrm{C}$ showed best decolorization results based on these results we can carry out further studies and device a eco friendly cost effective and efficient system for the degradation of leather dyes in the industrial effluents.

\section{REFERENCES}

[1] Adedayo O, Javadpour S, Taylor C, Anderson WA, Moo-Young M (2004) Decolourization and detoxification of methyl red by aerobic bacteria from a wastewater treatment plant. World $J$ Microbiol Biotech, 20: 545- 550.

[2] Awomeso JA, Taiwo AM, Gbadebo AM, Adenowo JA (2010). Studies on the pollution of waterbody by tannery industry effluents in Lagos, Nigeria. J Appl Sci Environ Sanit, 5:353359.

[3] Daneshvar N, Ayazloo M, Khatae AR, Pourhassan M (2007) Biological decolorization of dye solution containing malachite black by microalgae Cosmarium sp . Biores Technol, 98:1176- 1182.

[4] Gurulakshmi M, Sudarmani DNP, Venba R (2008) Biodegradation of leather acid dye by Bacillus subtilis. Advanced Biotech, 47: 2-8.

[5] Hu TL (1994) Decolourization of reactive azo dyes by transformation with Pseudomonas luteola. Biores Tech, 49: 47-51.
[6] Keharia H, Patel H, Madamwar D (2004) Decolorization screening of synthetic dyes by anaerobic methanogenic sludge using a Bacthdecoloration assay. World J Microbiol Biotechnol, 20: 365-370.

[7] Khehra MS, Saini HS, Sharma DK, Chadha BS, Chimni SS (2006). Biodegradation of azo dye C.I. Acid Red 88 by an anoxic-aerobic sequential bioreactor. Dyes and Pigments, 70:1-7

[8] Mathur N, Bhatnagar P, Bakre P (2006) Assessing mutagenicity of tannery dyes from Pali (Rajasthan) using Ames bioassay. Appl Ecol Environ Res, 4(1):111 - 118.

[9] Puvaneswari N, Muthukrishnan J, Gunasekaran $P$ (2006) Toxicity assessment and microbial degradation of azodyes. Ind J Exp Biol, 44:618626.

[10] Ponraj.M,Gokila.K,and Zambare Vasudeo(2011).Bacterial decolorization of textile Dye -Orange 3R.International Journal of advanced Biotechnology and Research.,2(1)168177

[11] Sasaki K, Sakai M, Matusita K, Masuda Y, Sato K (2008) Chemical structure analysis for azo type disperse dyes by mass spectroscopy and detection of dyestuff in tannery products causing allergic contact dermatitis. The Jap Soc Analyt Chem: Bunseki Kagaku, 57: 833-850.

[12] Saunders H, O Brien T, Nixon R (2004) Tannery dye allergic contact dermatitis following paraphenylenediamine sensitization from a temporary tattoo. Aus J Dermatol, 45(4):229 231.

[13] Shitole VH, Panvalkar SS (2000) Bioremediation of tannery effluent. J Emp Bio, $1(2): 10$..

[14] Tufekci N, Sivri N, Toroz I (2007) Pollutants of tannery industry wastewater and assessment of its discharge limits by water quality standards. Turk J Fish Aquat Sci, 7(2): 97- 103.

[15] Vilaseca M, Gutie MC, Grimau VL, Mesas ML, Crespi M (2010) Biological treatment of a tannery effluent after electrochemical oxidation of reactive dyes. Water Environ Res, 82(2):176-182. DOI:

[16] Wong PK, Yuen, PY (1996) Decolourization of synthetic dyes by Klebsiella pneumoniae RS13. Water Res, 30: 1736-1744.

[17] Yusuff RO, Sonibare JA (2004) Characterization of tannery industries effluents in Kaduna, Nigeria and pollution implications. Global Nest: The Int J, 6(3): 212 -221. 